\title{
ТЕРРОРИЗМ: ОПРЕДЕЛЕНИЕ И ВОЗМОЖНЫЕ ИСТОЧНИКИ ФИНАНСИРОВАНИЯ
}

\section{(C) 2019 Чернов Сергей Борисович}

кандидат экономических наук, доцент кафедры экономической теории и мировой экономики Государственный университет управления, Россия, Москва доцент Департамента экономической теории

Финансовый университет при Правительстве Российской Федерации, Россия, Москва

Email: chernov_s_b@mail.ru

В статье рассматриваются подходы к определению терроризма, анализируются возможные источники финансирования террористической деятельности, выделяются направления противодействия финансированию терроризма.

Ключевые слова: определение и причины терроризма, внутренние и внешние источники финансирования терроризма, противодействие финансированию терроризма.

В 2018 г. обстановка в сфере противодействия терроризму оставалась хотя и сложной, но контролируемой правоохранительными органами. За истекший год пресечена деятельность 37 экстремистских ячеек, ликвидированы 65 боевиков, задержаны 36 главарей, 236 бандитов и 589 пособников террористов, не допущены на территорию Российской Федерации более 10 тыс. подозреваемых в терроризме лиц, предотвращено несколько попыток использования беспилотных летательных аппаратов с целью совершения террористических актов, выявлено более 47 тыс. интернет-ресурсов, содержащих материалы, связанные с деятельностью международных террористических организаций, прекращена деятельность по распространению противоправной информации более чем 64 тыс. интернет-ресурсов [1].

По-прежнему полностью не исключена возможность использования сети Интернет для вербовки граждан России представителями международных террористических организаций, склонения новых завербованных лиц к совершению преступлений террористической направленности и оказания повторного влияния на лиц, решивших прекратить террористическую деятельность. Для совершения террористических атак могут использоваться боеприпасы как похищенные с внутренних складов хранения, так и привезенные с территорий вооруженных конфликтов за пределами Российской Федерации. Так же могут производиться и использоваться самодельные взрывные устройства.

Следует отметить, что наибольшее число преступлений террористической направленности выявляется в Северо-Кавказском федеральном округе. При этом руководители террористических группировок пытаются сформировать на территории Российской Федерации законспирированные ячейки, привлекая в них прежде всего представителей молодёжи.

Как правило, под терроризмом понимается политика систематического применения террора. Однако общепринятого определения этого понятия в настоящее время не существует из-за политизации данного вопроса. Наличие двойных стандартов в политике и экономике обуславливают различные подходы не только к определению терроризма, но и к различным представлениям о возможности присвоения статуса террористической организации тем или иным общественным формированиям. Поэтому двойные стандарты порождают конфликтные ситуации, способствуют теневизации экономики и усложняют борьбу с терроризмом [2].

В США терроризм рассматривается как предумышленное, политически мотивированное насилие, совершаемое против мирного населения или объектов субнациональными группами или подпольно действующими агентами, обычно с целью повлиять на настроение общества.

В России в соответствии с Федеральным законом от 06.03.2006 N35-ФЗ (ред. от 18.04.2018) «О противодействии терроризму» под терроризмом понимается идеология насилия и практика воздействия на принятие решения органами государственной власти, органами местного самоуправления или между- 
народными организациями, связанные с устрашением населения и (или) иными формами противоправных насильственных действий[3]. Террористическая деятельность включает в себя:

- организацию, планирование, подготовку, финансирование и реализацию террористического акта;

- подстрекательство к террористическому акту;

- организацию незаконного вооруженного формирования, преступного сообщества (преступной организации), организованной группы для реализации террористического акта, а равно участие в такой структуре;

- вербовку, вооружение, обучение и использование террористов;

- информационное или иное пособничество в планировании, подготовке или реализации террористического акта;

- пропаганду идей терроризма, распространение материалов или информации, призывающих к осуществлению террористической деятельности либо обосновывающих или оправдывающих необходимость осуществления такой деятельности.

Субъекты террористической деятельности осуществляют:

- организацию, планирование, подготовку, финансирование и реализацию террористического акта;

- подстрекательство к террористическому акту;

- организацию незаконного вооруженного формирования, преступного сообщества (преступной организации), организованной группы для реализации террористического акта, а равно участие в такой структуре;

- вербовку, вооружение, обучение и использование террористов;

- информационное или иное пособничество в планировании, подготовке или реализации террористического акта;

- пропаганду идей терроризма, распространение материалов или информации, призывающих к осуществлению террористической деятельности либо обосновывающих или оправдывающих необходимость осуществления такой деятельности.

Рассматривая террористическую деятельность можно выделить общие принципы ее организации и функционирования, которые необходимо учитывать при выявлении, раскрытии и расследовании преступлений террористической направленности: секретность; динамичность; отсутствие постоянного местоположения; насилие и коррупция как ключевые способы достижения целей террористических организаций. В основе террористической деятельности могут лежать псевдорелигиозные взгляды, социальные теории, национальные идеи либо их различные сочетания, доведенные до крайних экстремистских форм существования.

Таким образом, с одной стороны, терроризм можно рассматривать как идеологию насилия. С другой стороны, терроризм - это воздействие на общественное сознание, на принятие решений органами государственной власти, органами местного самоуправления или международными организациями посредством устрашения населения и (или) иными формами противоправных насильственных действий.

Террористическая деятельность, осуществляемая для достижения экономических целей с использованием ресурсов (труд, земля. капитал), является частью теневой экономики. Теневая экономика для беднейшей части населения может рассматриваться как источник выживания. При отсутствии законных источников дохода работа в террористической организации может рассматриваться отдельным человеком как благо, что особенно опасно в современных условиях социально-экономического кризиса и растущей социально-экономической дифференциации населения. По итогам исследования Института социологии РАН 59\% населения страны стараются дотянуть от аванса до зарплаты, в то время как по количеству долларовых миллиардеров Россия одна из преуспевающих стран в мире [4].

Для богатейшей части населения теневая экономика представляет источник роскоши и паразитического потребления (казино, рестораны, зарубежные увеселительные туры, порно индустрия и т.д.). Большие теневые доходы привлекают внимание организаторов террористических организаций для их теневого перераспределения в сферу террористической деятельности.

Таким образом, террористическая деятельность относится к черной форме теневой экономики. Запрещенная в соответствии с нормами уголовного права она превращается в криминальную экономику. В то же время теневая экономика является одной из финансовых основ развития терроризма, а усложнение социально- 
экономического положения страны послужит питательной почвой для возникновения радикальных экстремистских взглядов и вовлечения граждан в ряды террористических организаций.

Терроризм не может существовать без финансовых источников. Для осуществления террористических актов террористы несут материальные затраты, оплачивают труд наемников, закупают оборудование, транспорт, средства связи, подкупают должностных лиц государственных и муниципальных органов власти.

Таким образом, финансирование терроризма - это какие-либо действия, совершенные с целью финансового или материального обеспечения:

- отдельного террориста, террористической группы, организации;

- подготовки или совершения террористического акта;

- вовлечения в совершении террористического акта;

- публичных призывов к совершению террористического акта;

- содействия совершению террористического акта;

- создания террористической группы (организации).

Источники финансирования терроризма можно разграничить на внешние (поступают из-за рубежа) и внутренние (получаемые внутри страны). При этом внешние источники терроризма можно разделить на частные и государственные [5].

Характеризуя внешние источники, президент Чеченской республики Рамзан Кадыров в интервью Reuters заявил, что «Запад финансирует боевиков. Те, кто хотел разрушить Советский Союз, хотят разрушить и Российскую Федерацию, они стоят за ними» [6].

В любом случае финансирование терроризма оставляет документальные следы. Так, в результате спецоперации ФСБ по уничтожению боевиков в Хасавюрте была найдена кассовая книга, в которой подробно фиксировались все доходы и расходы на террористическую деятельность. Деньги поступали из Саудовской Аравии, Турции, Грузии и Азербайджана. Часть средств вымогалась у местных коммерсантов и нечестных на руку чиновников [7].

Угроза распространения международного терроризма для России по-прежнему остается вполне реальной. По данным МВД России в Гру- зии на военных базах иностранные инструкторы готовили террористические группы для осуществления терактов на территории Российской Федерации. В 2009 году количество преступлений террористического характера, в том числе подрывов и обстрелов, в Северо-Кавказском регионе возросло на 19\% и составило 637 случаев [8].

Внутренние источники, как правило, связаны с теневой экономикой. Террористы могут как сами получать теневые доходы, так и вымогать их у субъектов теневой экономики. В вышеуказанной кассовой книге были отметки о получении части средств в результате вымогательства у местных коммерсантов и нечестных на руку чиновников.

К внутренним источникам террористической деятельности можно отнести:

- доходы, полученные в теневой экономике;

- доходы, выведенные из легального оборота путем незаконного обналичивания денежных средств;

- безвозмездное использование имущества организаций и граждан, сочувствующих террористам;

- легальные источники, которые используются для прикрытия преступной деятельности и удовлетворения человеческих потребностей террористов.

Все это позволяет субъектам террористической деятельности получать и накапливать так называемые «грязные» деньги, которые в своем движении превращаются в криминальный капитал, используемый для извлечения криминальных доходов [9]. После возмещения затрат на противоправную деятельность полученный криминальный доход, как и любой другой доход, распадается на две части: фонд потребления (расходуется на покупку жилья, автомашин, турпутевок и т.д.) и фонд сбережений (обеспечивает теневые резервные накопления для их последующего реинвестирования в террористическую деятельность).

При распределении теневых благ и услуг в орбиту теневой экономики вовлекаются коррумпированные государственные и муниципальные служащие, что обеспечивает расширенное воспроизводство теневого капитала. До двух третей российских бизнесменов связаны с коррупцией, а более 50\% криминальных доходов в стране идет на подкуп должностных лиц [10]. 
Коррумпированность должностных лиц облегчает террористическую деятельность, ухудшает инвестиционную активность в регионах Российской Федерации, наиболее подверженных террористическим атакам.

Развернувшаяся в развитых странах мира цифровизация экономики таит в себе как возможности для развития общества, так и угрозы, в том числе в сфере противодействия терроризму. Ожидается, что уже в обозримом будущем искусственный интеллект приблизится к человеческому, а к 2075 году мыслительные процессы роботов будут неотличимы от человеческих. Это наряду с положительными результатами для мирового сообщества сформирует большую угрозу для развития всего человечества за счет роста численности безработных и обострения на этой основе социально-экономических проблем, а также возможности освоения искусственного интеллекта организованными преступными сообществами и террористическими организациями.

Финансирование терроризма предполагает скрытость совершаемых операций, что объясняет интерес к использованию крипто валют и крипто валютных кошельков в теневой экономике. Для совершения операций по покупке или продаже крипто валют, их использованию в сделках купли-продажи различных товаров и услуг необходимы электронные кошельки с очень высокой защищенностью. Крипто валютный кошелек представляет собой программное обеспечение, в котором хранятся уникальные пользовательские ключи для проведения финансовых операций по средствам децентрализованной технологии хранения и обработки данных о всех транзакциях с крипто валютой в сети Блокчейн (Blockchain).

Вне зависимости от целей пользователя, главными критериями выбора крипто валютного кошелька являются надежность и безопасность. Однако в теневой экономике главным критерием при выборе крипто-кошелька является его анонимность. Именно анонимность криптовалют, не позволяющая оперативно и досконально проводить расследование преступлений, привлекает внимание представителей террористических организаций к выбору вида криптовалют и крипто валютных кошельков.

Не меньшую опасность таит в себе угроза освоения телекоммуникационных и ядерных технологий террористическими организациями.
Это может происходить за счет коррупционного разложения органов государственной власти и проникновения представителей террористических организаций в сферы передовых технологий. О том, что это возможно свидетельствуют факты выявления преступных посягательств на компьютерные сети и программное обеспечение. Если в 2013 г. было зарегистрировано 11 тыс. IT-преступлений, то в 2016 г.- 66 тыс., а выявленный ущерб от подобных преступлений за первую половину 2017 г. превысил 18 млн. долл. [11].

Диалектика террористической деятельности такова, что террористы одиночки, не встречая должного противодействия со стороны правоохранительных органов и специальных служб, объединяются либо переходят в уже созданные террористические организации. Рост доходов террористических организаций, их объединение при полном развале легитимного государственного аппарата управления приводят к появлению террористических государств.

В качестве примера можно рассмотреть отчет, подготовленный группой разработки финансовых мер по борьбе с отмыванием денег (FATF), созданной в 1989 году по инициативе «Большой семерки». Российскую Федерацию в этой организации представляет Росфинмониторинг. Эксперты FATF обнародовали исследование основных источников дохода «Исламского государства». Основной годовой доход ИГИЛ в 2014 г. составлял более 1 млрд. долл. США и получался за счет продажи нефти и захвата банковских вкладов [12].

Другими источниками дохода ИГИЛ являются:

- использование сельскохозяйственных ресурсов, ИГИЛ контролировала $40 \%$ всех пшеничных полей Ирака и несколько комплексов зернохранилищ;

- выкупы за похищенных людей, приносящие доход в сумме от 20 млн. до 45 млн. долл. США в год.

В качестве внешних источников финансирования ИГИЛ используются:

- личные средства самих наемников, приезжающих в ИГИЛ из зарубежных стран. Средства могут быть как в денежной, так и в натуральной форме (оружие, боеприпасы, автомобили и другая техника);

- денежные переводы наемникам от их родственников, которые получают теневые доходы 
либо собирают деньги у лиц, сочувствующих террористическому государству ИГИЛ;

- денежные переводы от других лиц, согласных финансировать террористическую деятельность.

Для сбора средств и пропаганды идеалов террористических организаций активно используются социальные сети, вовлекается молодежь, в том числе из внешне благополучных семей.

Большие доходы, получаемые из разных источников, позволили ИГИЛ иметь в декабре 2014 г. террористическую армию численностью в 30 тыс. человек, из которых 19 тыс. являлись иностранными наемниками. По данным FATF, ежемесячный доход боевика составляет от 50 до 1500 долл. США, в среднем на боевика 350-500 долл. США, а в масштабах всей организации - 10 млн. долл. США.

Поэтому можно выделить особо государственный терроризм, который проявляется как государственное насилие против гражданских лиц как чужой, так и своей страны, и включает в себя незаконные задержания, убийства, похищения, пытки и казнь граждан без суда и следствия, выполняемые сотрудниками силовых или иных структур; финансирование и другую поддержку государством террористических группировок, действующих как на территории террористического государства, так и на территориях других суверенных государств; другие формы насилия над гражданскими лицами как чужой, так и сво- ей страны.

Учитывая существующие угрозы террористической опасности на современном этапе необходима консолидация деятельности всех государственных структур, институтов гражданского общества, средств массовой информации и каждого гражданина на основных направлениях противодействия терроризму. Ввиду особой опасности международной террористической организации ИГИЛ необходимо конструктивное взаимодействие всех антитеррористических сил не только внутри Российской Федерации, но и на международной арене.

Противодействие финансированию терроризма должно быть разнообразным и комплексным, поэтому на ряду с методами оперативно-разыскной работы необходимо:

- отслеживание подозрительных транзакций;

- установление адресных финансовых санкций по отношению к сочувствующим террористам физическим и юридическим лицам;

- уничтожение инфраструктуры черного рынка нефти;

- пресечение спонсирования террористов через социальные сети.

- формирование негативного образа участников террористических организаций;

- запрещение героизации лидеров террористической деятельности с установлением внушительной ответственности за ее нарушение.

\section{Библиографический список}

1. Обстановка сложная, но контролируемая»: в НАК подвели итоги борьбы с терроризмом в 2018 году.- Режим доступа: https://russian.rt.com/russia/article/581846-nak-protivodeistvie-terrorizm-itogi-2018 (дата обращения 11.12.2018).

2. Чернов С.Б. Двойные стандарты в экономической политике и теневая экономика// Вестник университета (Государственный университет управления).- М.: ГУУ, № 9, 2016 г., с. 105-110.

3. Федеральный закон от 06.03.2006 N35-Ф3 (ред. от 18.04.2018, с изм. от 29.03.2019) «О противодействии терроризму».

4. Лавров, А. Три мифа о доходах малообеспеченных / А. Лавров [Электронный ресурс].- Режим доступа: http://kp.ru/print/article/24138/356573/ (дата обращения: 30.11.2017).

5. Чернов С.Б. Противодействие финансированию терроризма: монография / С.Б. Чернов; Государственный университет управления.-М.: Издательский дом ГУУ, 2018.- 128 с.

6. Зегонов О. Кадыров: боевиков на Северном Кавказе финансирует Запад. /Infox.ru - Режим доступа: http:// www.infox.ru/authority/defence/2009/12/21/Kadyyrov_boyeviki_Za.phtml (дата обращения: 27.06.2019).

7. «Чёрная» бухгалтерия дагестанских боевиков раскрывает тайны бандподполья. «Вести.Ru», 2 января 2010,Режим доступа: https://www.vesti.ru/doc.html?id=334149(дата обращения: 27.06.2019).

8. Олисаева Альбина. Иностранцы готовят в Грузии террористов для диверсий в России - МВД РФ. РИА Новости, 15 января 2010.- Режим доступа: https://ria.ru/20100114/204528151.html(дата обращения: 27.06.2019).

9. Чернов С.Б. Отмывание криминального капитала как угроза безопасности экономики России. / / Вестник университета (Государственный университет управления). - М.: ГУУ, № 2, 2016 г., с. 98-105. 
10. Ущерб от коррупции в России может достигать $\$ 20$ млрд.- глава МВД- Режим доступа: https://ria. ru/20080924/151563762.html (дата обращения: 27.06.2019).

11. Данные Прокуратуры РФ [Электронный ресурс].- Режим доступа: http://www.tadviser.ru/index.php/Cтатья: Киберпреступность_и_киберконфликты_:Россия\#.D0.94.D0.B0.D0.BD.D0.BD.D1.8B.D0.B5_.D0.9F.D1.80. D0.BE.D0.BA.D1.83.D1.80.D0.B0.D1.82.D1.83.D1.80.D1.8B_.D0.A0.D0.A4 (дата обращения: 30.11.2017).

12. Макаренко Г. Эксперты оценили годовой «доход» ИГИЛ в \$1 млрд. / РБК - Режим доступа: https://www.rbc. ru/politics/04/03/2015/54f5c0419a79474b0aa0dc39(дата обращения 4.03.2015 г.).

13. Стерликов Ф.Ф. Экономическая теория ценности блага как интегратор трудовой теории стоимости и теории трудовой предельной полезности. Вопросы экономики и права. 2012. № 50. С. 27-31. 